\title{
ANALISIS DETERMINAN STRUKTUR MODAL INDUSTRI TELEKOMUNIKASI DI INDONESIA
}

\author{
DETERMINANT ANALYSIS OF CAPITAL STRUCTURE OF THE TELECOMMUNICATION \\ INDUSTRY IN INDONESIA
}

\author{
Risty Kartika Febrianty ${ }^{* 1}$, Tanti Novianti**), dan Arief Tri Hardiyanto***) \\ ${ }^{*}$ Sekolah Bisnis, IPB University \\ Jl. Pajajaran Bogor 16151 \\ **) Departemen Ilmu Ekonomi, Fakultas Ekonomi dan Manajemen, IPB University \\ Jl. Agatis Kampus IPB Darmaga, Bogor 16680 \\ ${ }^{* * *}$ Fakultas Ekonomi, Universitas Pakuan \\ Jl. Pakuan Bogor 16143
}

\begin{abstract}
This paper aimed to investigate the determinants of the capital structure of the telecommunication industry in Indonesia. The data covered the years of 2011-2017. The sample was the listed-telecommunication companies listed on the Indonesia Stock Exchange (IDX). The partial adjustment model used to identify the impact of determinant factors, namely profitability, age, risk, size, and growth on capital structure decision. The dynamic regression found that profitability, age, risk, and growth had a significant effect on TLKM capital structure. The profitability, age and size had a significant effect on ISAT capital structure. The age, risk and size had significant effect on EXCL capital structure While, no variables had a significant effect on FREN capital structure. Those factors were important to the executives in restructuring capitals or other financial decisions. This study provided insight for the potential investors and banks in evaluating risks associated with investment and loan in telecommunication companies.
\end{abstract}

Keywords: capital structure, partial adjustment model, telecommunication

\begin{abstract}
Abstrak: Penelitian ini bertujuan menginvestigasi determinan struktur modal industri telekomunikasi di Indonesia. Data yang digunakan dalam penelitian ini adalah selama periode tahun 2011-2017. Sampel yang digunakan adalah perusahaan telekomunikasi yang terdaftar pada Bursa Efek Indonesia (BEI). Analisis menggunakan partial adjustment model untuk mengidentifikasi faktor profitabilitas, usia, ukuran, risiko dan pertumbuhan terhadap struktur modal. Hasil analisis regresi dinamis menunjukan variabel yang berpengaruh signifikan terhadap perusahaan telekomunikasi berbeda-beda antar perusahaan. Profitabilitas, usia, risiko dan pertumbuhan berpengaruh signifikan terhadap struktur modal TLKM, sementara profitabilitas, usia dan ukuran berpengaruh signifikan terhadap struktur modal ISAT, usia, risiko dan ukuran berpengaruh signifikan terhadap struktur modal EXCL dan tidak ditemukan variabel yang berpengaruh signifikan pada FREN. Hasil penelitian dapat menjadi pertimbangan bagi manajer perusahaan telekomunikasi di Indonesia untuk mempertimbangkan faktor determinan tersebut saat melakukan perubahan dalam pemodalan atau keputusan finansial lainnya. Hasil penelitian juga memberikan infomasi bagi investor dan perbankan terkait risiko investasi dan peminjaman bagi perusahaan telekomunikasi.
\end{abstract}

Kata kunci: partial adjustment model, struktur modal, telekomunikasi

\footnotetext{
${ }^{1}$ Alamat Korespondensi:

Email: ristykartikafebrianty@gmail.com
} 


\section{PENDAHULUAN}

Terjadi perubahan teknologi pada industri telekomunikasi yang menyebabkan pergeseran tren penggunaan layanan seluler yang semula dari voice dan SMS menjadi layanan data. Meningkatnya pertumbuhan layanan data memerlukan pita frekuensi yang lebih lebar dan sesuai dengan teknologi yang berkembang. Dengan demikian, operator telekomunikasi perlu melakukan investasi agar dapat terus eksis di bisnis telekomunikasi. Investasi tersebut diantaranya untuk pengembangan infrastrukur layanan dalam rangka meningkatkan kualitas, mengakuisisi pelanggan ataupun ekspansi bisnis.

Untuk keperluan investasi dan operasional, dana perusahaan berasal dari dua sumber dana yaitu sumber dana internal dan sumber dana eksternal. Dengan adanya dua sumber tersebut, maka perusahaan perlu menentukan struktur modalnya (Komara, 2015). Dalam manajemen keuangan proporsi antara jumlah dana dari dalam dan luar perusahaan dikenal dengan struktur modal. Struktur modal merupakan rasio utang dengan ekuitas.

Terdapat sebuah fenomena yang terjadi pada sektor telekomunikasi di Indonesia yaitu meningkatnya Return on Equity (ROE) industri. Meningkatnya ROE ini mengindikasikan bahwa perusahaan menggunakan lebih banyak utang sebagai pembiayaan dibanding ekuitas. Sebagai perusahaan yang mengandalkan pendanaan melalui utang, maka perlu dianalisis lebih dalam pola kebijakan struktur modal perusahaan.

Tujuan dari mengelola struktur modal adalah untuk mengkombinasikan sumber daya keuangan yang digunakan oleh perusahaan dalam suatu cara yang akan memaksimalkan kesejahteraan shareholders dan meminimalkan biaya modal. Struktur modal sangat penting bagi perusahaan karena strutur modal menentuan kemampuan perusahaan untuk memenuhi kebutuhan stakeholders (Fama et al. 2015; Sivathaasan, 2013). Dalam beberapa penelitian terdahulu juga dijelaskan bahwa penentuan sruktur modal menjadi penting karena pilihan pembiayaan yang membentuk struktur modal akan memiliki pengaruh terhadap profitabilitas (Acaravci, 2015; Alipour et al. 2015; Yoshendy et al. 2015; Majumdar dan Chhiber, 2014; Sitorus, 2014; Yoshendy, 2014).

Keputusan struktur modal memiliki peran yang signifikan. Dampak keputusan struktur modal mempengaruhi risiko dan tingkat imbal hasil pemegang saham. Keputusan untuk menggunakan lebih banyak utang akan meningkatkan biaya, menurunkan profit dan pada level utang tertentu akan membawa perusahaan pada bahaya kebangkrutan. Disisi lain, menggunakan lebih banyak ekuitas dapat menurunkan profit perusahaan karena perusahaan meningkatkan imbal hasil pemegang saham. Komponen ekuitas yang lebih besar menyebabkan pembagian profit yang lebih kecil bagi perusahaan. Oleh sebab itu, perusahaan perlu menentukan pembiayaan yang paling tepat untuk memaksimalkan nilai perusahaan. Kondisi struktur modal perusahaan telekomunikasi di Indonesia yang terdaftar pada Bursa Efek Indonesia (BEI) selama tahun 2011-2017 ditunjukkan pada Tabel 1 dengan menggunakan debt to equity ratio (DER) sebagai proksi struktur modal.

Berdasarkan Tabel 1, terdapat pola pembiayaan yang berbeda antar perusahaan telekomunikasi meskipun berada dalam satu industri. Pada umumnya perusahaan yang berada dalam satu industriyang sama akanmemiliki struktur modal yang sama. Meskipun demikian, tidak menutup kemungkikan perusahaan dalam satu industri memiliki pola pembiayaan yang berbeda, sebagaimana dijelaskan dalam Sitorus (2014).

Tabel 1. Debt to Equity Ratio Sektor Telekomunikasi di BEI periode 2011-2017

\begin{tabular}{lccccccc}
\hline Perusahaan & \multicolumn{7}{c}{ Tahun } \\
\cline { 2 - 8 } & 2011 & 2012 & 2013 & 2014 & 2015 & 2016 & 2017 \\
\hline TLKM & 0,690 & 0,663 & 0,653 & 0,649 & 0,779 & 0,702 & 0,770 \\
ISAT & 1,773 & 1,847 & 2,301 & 2,751 & 3,176 & 2,586 & 2,419 \\
EXCL & 1,276 & 1,307 & 1,632 & 3,563 & 3,176 & 1,588 & 1,604 \\
FREN & 2,762 & 1,877 & 4,202 & 3,482 & 2,023 & 2,886 & 1,608 \\
\hline
\end{tabular}


Pada Tabel 1, tiga dari empat perusahaan telekomunikasi memiliki DER diatas 1. Angka DER diatas satu mengindikasikan perusahaan menggunakan lebih banyak utang dibanding ekuitas, sehingga menggambarkan perusahaan memiliki risiko kebangkrutan. TLKM menunjukkan DER yang paling rendah dengan rasio dibawah 1 . ISAT dan EXCL memiliki DER diatas satu. Sementara itu, perusahaan dengan DER paling tinggi adalah FREN dengan DER sebesar 4.202, yang artinya perusahaan memiliki utang empat kali lebih besar dibanding ekuitasnya. Dengan demikian mengindikasikan perusahaan memiliki risiko kebangkrutan yang besar.

Perbedaan DER pada perusahaan telekomunikasi perlu digali lebih dalam, yaitu terkait faktor apa saja yang mempengaruhi perbedaan tersebut. Berdasarkan kajian empiris, salah satu faktor yang dapat mempegaruhi struktur modal adalah karakteristik internal perusahaan. Beberapa karakteristik internal perusahaan yang terbukti memiliki pengaruh terhadap struktur modal adalah tingkat keuntungan (profitability), umur perusahaan (age), ukuran perusahaan (size), risiko (risk), dan pertumbuhan (growth) sebagaimana dipaparkan pada penelitian sebelumnya (Untung et al. 2017; Hardiyanto, 2014; Utomo dan Djumahir, 2013).

Karakteristik internal perusahaan akan menjadi determinan perusahaan sekaligus menjadi variabel independen penelitian. Sementara variabel dependen pada penelitian ini adalah DER. DER dianggap dapat mewakili struktur modal suatu perusahaan (Hardiyanto, 2014; Sitorus, 2014; Ahmed, 2012; Gittman, 2010; Lasher, 2003).

Berdasarkan penjelasan maka perlu diteliti lebih dalam faktor karakteristik perusahaan yang mempengaruhi struktur modal. Hasil yang diharapkan adalah dapat diketahui faktor apa saja yang menpengaruhi struktur modal pada masing-masing perusahaan. Data akan diolah menggunakan model dinamis dengan pendekatan partial adjustment model (PAM). Hal ini dikarenakan tingkat struktur modal optimal suatu perusahaan tidak dapat diukur secara langsung (unobservable), namun struktur modal model dinamis dapat memperkirakan hal tersebut. Analisis menggunakan metode statis struktur modal dapat menyebabkan beberapa fokus penelitian terabaikan. Heshmati (2001) mengatakan bahwa hasil pengukuran struktur modal dengan pendekatan statis dapat menimbulkan deviasi dari tingkat utang optimalnya. Kerangka statis struktur modal tidak dapat menangkap dinamika bisnis perusahaan. Oleh sebab itu, pendekatan dalam penelitian ini menggunakan pendekatan dinamis.

\section{METODE PENELITIAN}

Objek penelitian adalah perusahaan telekomunikasi yang terdaftar pada Bursa Efek Indonesia (BEI) selama periode tahun 2011-2017. Terdapat lima perusahaan telekomunikasi yaitu PT Bakrie Telecom, Smartfren Telecom, Indosat, PT. Telekomunikasi Indonesia, dan PT XL Axiata. Sampel penelitian hanya menggunakan empat perusahaan. Hal ini dikarenakan satu perusahaan yaitu Bakrie Telecom, tidak memiliki laporan keuangan yang lengkap dan memiliki nilai ekuitas minus sehingga dikeluarkan dari penelitian. Data yang digunakan pada penelitian ini adalah data sekunder, yaitu laporan keuangan triwulanan perusahaan selama periode tahun 2011-2017.

Variabel penelitian terdiri dari variabel bebas (independent variabel) dan variabel terikat (dependent variabel). Variabel bebas terdiri dari profitability, age, risk, size, dan growth sedangkan variabel terikatnya adalah DER. Profitability adalah adalah kemampuan perusahaan untuk menghasilkan laba. Pada penelitian ini proksi profitabilitas yang digunakan adalah NPM (Net Profit Margin) yang dihitung dengan membagi net income terhadap sales. Age adalah usia perusahaan yang dihitung sejak tanggal perusahaan IPO perusahaan sampai tanggal 31 Desember 2017. Risk adalah risiko perusahaan yang dalam penelitian ini diukur dengan menggunakan standar deviasi cash flow. Volatilitas arus kas mencerminkan risiko perusahaan tidak dapat memenuhi kewajiban membayar beban bunga. Size adalah ukuran perusahaan yang dalam penelitian ini dinyatakan dengan log natural dari total aset. Dalam perspektif teori trade off dan agency theory, size memiliki hubungan yang positif terhadap struktur modal. Growth dalam penelitian ini adalah pertumbuhan perusahaan yang dihitung dengan menggunakan proksi penjualan. Variabel dependen pada penelitian ini adalah DER yang dihitung dengan membagi total debt kepada total equity.

Teknik analisis data yang digunakan adalah regresi dengan pendekatan dinamis partial adjustment model. Pada realita seringkali ditemui hubungan antara peubah endogen (Y) dan eksogen (X) tidak berlangsung seketika, yaitu terjadi pada waktu (t) yang sama. Peubah 
endogen $(\mathrm{Y})$ seringkali dipengaruhi oleh beberpa faktor, yaitu peubah eksogen $(\mathrm{X})$ yang terjadi pada periode sebelumnya (lag), perubah endogen (Y) itu sendiri yang terjadi pada periode sebelumnya (lag), atau gabungan anata keduanya (Firdaus, 2011).

Model yang melibatkan unsur kelembaman (lag) pada peubah eksogen $(\mathrm{X})$ disebut distributed lag model sementara model yang melibatkan unsur kelembaman (lag) pada peubah endogen (Y) disebut autoregressive distributed lag model. Kelembaman terjadi karena faktor psikologis, teknologi dan institusi. Salah satu bentuk ekonometrika dinamis autoregressive distributed lag model adalah partial adjustment model. PAM adalah bagian dari ekonometrika dinamis yang memasukkan unsur lag dari peubah dependen sebagai regresor dalam regresi (Firdaus, 2011). Dalam model ini variabel terikat dilambangkan $\mathrm{Y}^{*}$ merupakan suatu nilai optimal yang diharapkan. Persamaan linear model ini dituliskan sebagai berikut:

$$
\mathrm{Y}^{*}=\beta_{0}+\beta_{1} \chi_{\mathrm{t}}+\mathrm{u}_{\mathrm{t}}
$$

$\mathrm{Y}^{*}$ adalah variabel terikat yang diharapkan $\mathrm{Xt}$ adalah variabel bebas yang diduga akan mempengaruhi $\mathrm{Yt}^{*}$ dan ut (error). Nilai Y yang diharapkan tidak dapat diobservasi secara langsung oleh sebab itu Nerlove mengasumsikan suatu hipotesis yang dikenal sebagai hipotesis partial adjustment model sebagai berikut:

$$
\left(\mathrm{Y}_{\mathrm{t}}-\mathrm{Y}_{\mathrm{it}-1}\right)=\lambda\left(\mathrm{Y}_{\mathrm{t}}^{*}-\mathrm{Y}_{\mathrm{it}-1}\right)
$$

Dimana: $Y_{t}-Y_{i t-1}$ (perubahan nilai $Y$ yang sebenarnya); $\mathrm{Y}^{*}{ }_{\mathrm{t}}-\mathrm{Y}_{\mathrm{it}-1}$ (perubahan nilai $\mathrm{Y}$ yang diharapkan); $\lambda$ (koefisien penyesuaian $(0<\lambda \leq 1)$ ).

Metode yang digunakan adalah least square method. Hal ini dikarenakan terdapat endogenitas dalam data penelitian. Endogenitas adalah suatu kondisi dimana satu atau beberapa variabel eksplanatori memiliki hubungan dengan residualnya. Faktor yang menyebabkan terjadinya masalah ini diantaranya adalah model regresi memasukkan lag dari variabel dependen sebagai variabel independen (Effendi dan Setiawan, 2014). Hal tersebut terjadi pada penelitian ini karena memasukkan lag DER (DERt-1) pada variabel independen. Dalam Effendi dan Setiawan (2014) dijelaskan untuk mengatasi masalah tersebut dapat menggunakan least square method. Asteriou dan Hall (2007) juga menjelaskan bahwa least square method dapat digunakan untuk mengolah PAM.
Model yang digunakan untuk menunjukkan target struktur modal pada perusahaan i tahun ke $t$ adalah DER*it. Dimana DER*it adalah fungsi dari seperangkat variabel karakteristik perusahaan Xit.

$$
\mathrm{DER}_{\mathrm{it}}^{*}=\beta \mathrm{X}_{\mathrm{it}}+\mu_{\mathrm{it}}
$$

Perubahan struktur modal antar perusahaan dan antar waktu diestimasi dengan menggunakan penyesuaian parsial(PAM)(Hendrawan dan Nugraha, 2015; Flannery dan Rangan, 2006). Persamaan yang digunakan adalah sebagai berikut:

$$
\left(\mathrm{DER}_{\mathrm{it}}-\mathrm{DER}_{\mathrm{it}-1}\right)=\lambda\left(\mathrm{DER}_{\mathrm{it}}^{*}-\mathrm{DER}_{\mathrm{it}-1}\right)
$$

Untuk mengukur pengaruh variabel penelitian terhadap struktur modal dengan mengikutsertakan DER yang merupakan variabel dependen sebagai regresor dalam regresi menggunakan rumus sebagai berikut:

$$
\operatorname{DER}_{\mathrm{it}}=(\lambda \beta) \mathrm{X}_{\mathrm{it}}+(1-\lambda) \mathrm{DER}_{\mathrm{it}-1}+\lambda \mu_{\mathrm{it}}
$$

Model akhir yang digunakan untuk mengukur varibel determinan perusahaan terhadap struktur modal adalah sebagai berikut, dimana Vektor Xit adalah karakteristik perusahaan yaitu profitability, age, risk, size, dan growth:

$$
\mathrm{DER}_{\mathrm{it}}=\gamma_{0} \mathrm{DER}_{\mathrm{it}}+\sum_{\mathrm{k}} \gamma_{\mathrm{k}} \mathrm{X}_{\mathrm{it}}+v_{\mathrm{it}}
$$

Adapun kerangka pemikiran penelitian ini adalah sebagaimana tercantum pada Gambar 1. Struktur modal suatu perusahaan diantaranya dipengaruhi oleh faktor internal perusahaan yang menjadi variabel determinan. Kriteria perusahaan sebagai faktor internal turut menentukan struktur modal perusahaan. Melalui purposive sampling, sampel yang diambil berupa perusahaan telekomunikasi yang terdaftar di Bursa Efek Indonesia periode 2011-2017. Tahapan pertama dilakukan uji multikolinieritas, autokorelasi, heteroskedastisitas, dan uji normalitas. Kemudian setelah semua asumsi terpenuhi dilakukan regresi dinamis dengan pendekatan partial adjustment model untuk mengetahui pengaruh dan hubungan variabel penelitian terhadap struktur modal.

Faktor internal perusahaan yang digunakan sebagai variabel penelitian adalah tingkat keuntungan (profitability), umur perusahaan (age), risiko (risk) denganmenggunakan proksivolatilitas aruskas (SDCF), ukuran perusahaan (size) dan pertumbuhan (growth). 
Berdasarkan pada penelitian terdahulu, variabel ini terbukti memiliki pengaruh terhadap struktur modal. Meskipun demikian, hasil menunjukkan hasil yang diberikan berbeda-beda.

Profitabilitas memiliki pengaruh negatif signifikan terhadap struktur modal, yaitu apabila profitabilitas meningkat maka tingkat penggunaan utang akan menurun dibanding dengan penggunaan ekuitas, atau dengan kata lain tingkat penggunaan ekuitas meningkat dibanding tingkat penggunaan utang (Acaravci, 2015; Alipour et al.. 2015; Majumdar 2014; Sitorus 2014; Yoshendy, 2014; Bayrakdaroglu et al. 2013; Yartey dan Abor, 2013). Usia perusahaan dalam struktur modal merupakan salah satu standar pengukuran reputasi perusahaan. Petersen dan Rajan dalam Abor (2009) mengatakan bahwa perusahaan dengan usia yang lebih lama akan memiliki rasio utang lebih tinggi karena memiliki kualitas yang lebih baik.

Risk diproksikan dengan volatilitas arus kas (SDCF). Hasil kajian empiris mengatakan bahwa risk berpengaruh negatif terhadap struktur modal perusahaan. Karakteristik selanjutnya adalah ukuran perusahaan (size) yang diproksikan dengan menggunakan total asset. Hasil kajian empiris mengatakan bahwa struktur modal perusahaan akan meningkat seiring dengan meningkatnya total aset perusahaan (Kpuki dan Said, 2012; Muzir, 2011; Bhaird dan Lucey, 2010; Brigham dan Houston, 2006). Pertumbuhan (growth) diproksikan menggunakan pertumbuhan sales. Berdasarkan kajian empiris, growth berpengaruh positif terhadap struktur modal perusahaan (Abor dan Biekpe 2007; Hall et al. 2004; Heshmati 2001). Berdasarkan penjelasan maka hipotesis dalam penelitian ini adalah sebagai berikut:

H1 : Profitabilitas (profitability) memiliki pengaruh negatif terhadap struktur modal
H2 : Umur perusahaan (age) berpengaruh positif terhadap struktur modal

H3 : Risiko (risk) berpengaruh negatif terhadap struktur modal perusahaan

H4 : Ukuran perusahaan (size) berpengaruh positif terhadap struktur modal perusahaan

H5 : Pertumbuhan (growth) berpengaruh positif terhadap struktur modal perusahaan

\section{HASIL}

Statistik deskriptif atas data struktur modal dan variabel yang digunakan pada empat perusahaan telekomunikasi di Indonesia selama periode tahun 2011 sampai 2017 disajikan pada Tabel 2. Berdasarkan Tabel 2 dapat kita lihat bahwa rerata struktur modal perusahaan sebesar 1.961 yang ditujukan oleh variabel DER sebagai proksi struktur modal. Rerata profitability sebesar -0.138 , rerata age sebesar 5.003, rerata risk sebesar 5.051, rerata size sebesar 10.783, dan rerata growth sebesar 0.306 .

Rerata struktur modal perusahaan sebesar 1,961 yang berarti bahwa perusahaan lebih banyak menggunakan utang sebagai pembiayaan perusahaan dibanding ekuitas. Standar deviasi 1,022 menunjukkan bahwa keragaman struktur modal juga tinggi diantara perusahaan. Nilai DER tertinggi sebesar 4,202 dan DER terendah sebesar 0,581. Nilai DER 4,202 mengindikasikan bahwa perusahaan menghadapi risiko yang tinggi karena utang perusahaan lebih besar daripada ekuitasnya. Risiko ini berkaitan dengan kemungkinan gagal bayar utang. Sementara nilai DER 0,58 mengindikasikan bahwa terdapat perusahaan yang mempertimbangkan pendanaan internal untuk mengkontrol risiko perusahaan.

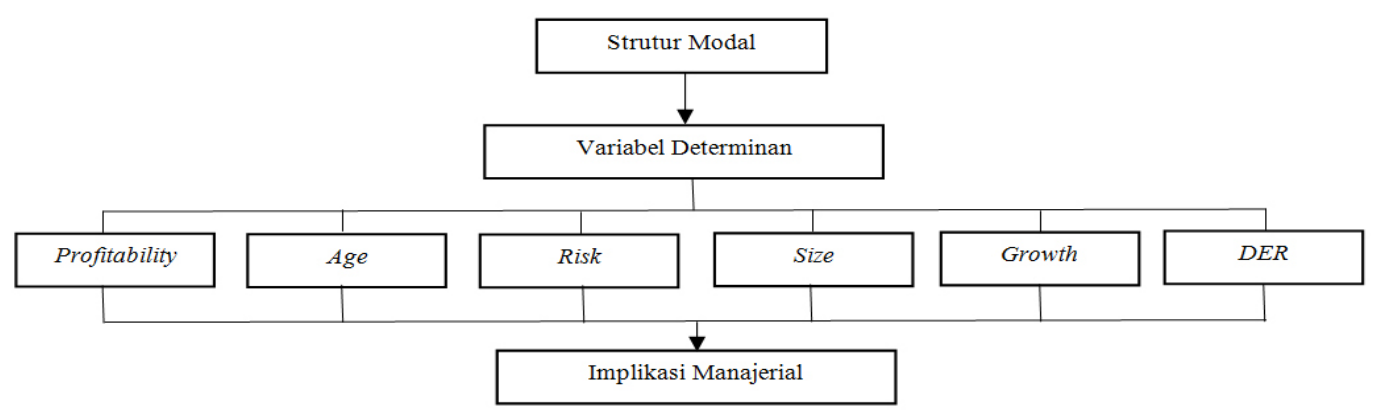

Gambar 1. Kerangka pemikiran penelitian 
Tabel 2, Statistik deskriptif

\begin{tabular}{lcccccc}
\hline Statistic & $\mathrm{N}$ & Min & Max & Mean & Median & Std, Dev \\
\hline Profitability & 112 & $-2,515$ & 0,302 & $-0,138$ & 0,025 & 0,508 \\
Age & 112 & 3,951 & 5,630 & 5,003 & 5,105 & 0,484 \\
Risk & 112 & $-0,371$ & 8,056 & 5,051 & 5,072 & 1,632 \\
Size & 112 & 8,774 & 12,198 & 10,783 & 10,870 & 0,790 \\
Growth & 112 & $-0,766$ & 1,148 & 0,306 & 0,484 & 0,653 \\
DER & 112 & 0,581 & 4,202 & 1,961 & 1,786 & 1,022 \\
\hline
\end{tabular}

Rerata profitabilitas $-0,138$ mengindikasikan bahwa terjadi inefficiency dalam bisnis industri telekomunikasi karena perusahaan tidak mampu menghasilkan laba selama periode tesebut. Profitabilitas maksimal $(0,302)$ mengindikasikan bahwa perusahaan masih memiliki harapan untuk tumbuh positif. Sementara nilai profitabilitas terendah sebesar -2,515 mengindikasikan bahwa industri secara keseluruhan menghadapi kerugian. Hal ini sejalan dengan kondisi industri yang dijelaskan oleh Maharani dan Wulandari (2014) bahwa meskipun jumlah pengguna telekomunikasi atau dalam hal ini pengguna seluler tumbuh tapi pendapatan perusahaan telekomunikasi cenderung mengalami penurunan.

Growth yang digunakan pada penelitian ini adalah pertumbuhan sales. Rerata growth perusahaan sebesar 0,306 dan nilai terendah sebesar -0.766 hal ini mengindikasikan bahwa selama periode amatan, perusahaan menghadapi penurunan dalam penjualan sehingga menyebabkan pertumbuhan negatif. Meskipun demikian, masih terdapat prospek untuk industri ini karena nilai tertinggi growth sebesar 1,48. Angka ini menunjukkan bahwa masih terdapat peluang untuk perusahaan dalam industri telekomunikasi mengalami pertumbuhan positif. Hal ini juga didukung oleh nilai rerata growth industri yang positif. Sementara itu, untuk size yang digambarkan oleh log natural total aset perusahaan menunjukkan aset paling tinggi sebesar 12,198 yang dimiliki oleh Telkom dan aset paling kecil sebesar 8,778 yang dimiliki oleh Smartfren Telecom.

Selanjutnya, akan dipaparkan hasil uji analisis regresi dinamis variabel penelitian terhadap struktur modal. Dalam melakukan analisis regresi dilakukan beberapa uji seperti uji asumsi klasik, uji F, uji t dan uji koefisien determinasi. Hasil uji menunjukkan semua asumsi terpenuhi. Rekapitulasi hasil perbandingan model regresi dinamis perusahaan telekomunikasi disajikan pada Tabel 3.
Hasil uji regresi dinamis menunjukkan bahwa variabel penelitian memiliki pengaruh pada struktur modal perusahaan. Artinya, setiap perubahan pada variabel penelitian (profitability, age, risk, size dan growh) akan mempengaruhi stuktur modalnya. Meskipun demikian, pengaruh dan hubungan yang dihasilkan berbeda antar perusahaan. Untuk mengetahui perbedaan hubungan pada antar perusahaan, pembahasan hasil uji akan disajikan sesuai variabel penelitian yang digunakan.

\section{Profitability}

Tabel 3 menunjukkan variabel profitability memiliki pengaruh negatif signifikan pada TLKM dan ISAT. Sementara memiliki pengaruh tidak signifikan pada EXCL dan FREN. Hasil estimasi pada TLKM diperoleh nilai probabilitas sebesar 0.005 dengan nilai koefisien -1,094. Sementara itu, hasil estimasi pada ISAT menunjukkan nilai probabilitas sebesar 0.011 dengan nilai koefisien -1.319. Berdasarkan hasil tersebut maka H0 ditolak.Artinya profitability memiliki pengaruh negatif signifikan terhadap besarnya Debt to Equity Ratio (DER) pada perusahaan TLKM dan ISAT. Tanda negatif pada koefisien menunjukkan bahwa variabel profitabilitas memiliki hubungan negatif terhadap struktur modal. Hal ini memberikan pengertian bahwa peningkatan profitabilitas akan menurunkan DER perusahaan dan sebaliknya.Penelitian yang dilakukan oleh Acaravci (2015), Alipour et al. (2015), Yoshendy (2015), Sitorus (2014) juga menunjukkan hasil yang sama yaitu profitabilitas memiliki hubungan negatif signifikan terhadap struktur modal.

Perusahaan dengan profitabilitas yang lebih tinggi akan mempunyai banyak dana internal dibanding perusahaan dengan profitabilitas rendah. Oleh sebab itu, perusahaan akan menggunakan utang lebih kecil karena perusahaan mampu menyediakan dana yang cukup melalui laba ditahan. Hasil penelitian ini sesuai dengan pecking order theory yang menyatakan bahwa 
perusahaan lebih memilih menggunakan dana internal daripada pendanaan eksternal untuk membiayai kebutuhan modalnya.

Age

Petersen dan Rajan dalam Abor (2009) mengatakan bahwa perusahaan dengan usia yang lebih lama akan memiliki rasio utang lebih tinggi karena memiliki reputasi kualitas yang lebih baik. Reputasi ini berkaitan dengan creditworthiness yang akan dievaluasi oleh bank sebelum memberikan pinjaman kepada perusahaan. Hasil regresi pada Tabel 2 menunjukkan age memiliki pengaruh positif signifikan pada TLKM dan ISAT. Sementara age memiliki pengaruh negatif signifikan pada EXCL dan tidak memiliki pengaruh signifikan pada FREN.

Hasil estimasi pada TLKM diperoleh nilai probabilitas sebesar 0,002 dengan nilai koefisien 0,296. Sementara itu, hasil estimasi pada ISAT menunjukkan nilai probabilitas sebesar 0.002 dengan nilai koefisien 1.546. Berdasarkan hasil tersebut maka H0 ditolak. Artinya age memiliki pengaruh positif signifikan terhadap besarnya Debt to Equity Ratio (DER) pada perusahaan TLKM dan ISAT. Tanda positif mengindikasikan bahwa setiap penambahan usia perusahaan akan meningkatkan DER perusahaan. Hal ini dapat dijelaskan oleh trade off theory yang mengatakan bahwa semakin bertambah usia perusahaan, semakin mudah dalam mengakses utang karena dianggap memiliki reputasi yang lebih baik dibandingkan perusahaan yang baru berdiri dan belum memiliki credit history. Hasil penelitian ini mendukung penelitian terdahulu yang dilakukan oleh Avarmaa et al. (2011), Abor (2009). Seiring bertambahnya usia perusahaan, kinerja perusahaan akan akan semakin mudah diakses, sehingga asimetri informasi menurun dan menyebabkan utang yang lebih tinggi (Avarmaa et al.2011).

Hasil yang berbeda ditemukan pada EXCL, yaitu variabel age memiliki pengaruh negatif signifikan yang ditunjukkan dengan nilai probability sebesar 0.000 dan nilai koefisien sebesar -1.176. Dalam Avarma et al.. (2011) dijelaskan hal ini mungkin terjadi apabila perusahaan menganut prinsip pecking order theory yang berasumsi semakin lama perusahaan berada dalam suatu bisnis, akan semakin semakin menghasilkan banyak profit sehingga menurunkan utang.

\section{Risk}

Risk adalah risiko perusahaan yang dalam penelitian ini diukur dengan menggunakan standar deviasi cash flow. Volatilitas arus kas mencerminkan risiko perusahaan tidak dapat memenuhi kewajiban membayar beban bunga. Jumlah beban bunga dan angsuran utang akan secara langsung mempengaruhi perubahan nilai arus kas. Semakin tinggi volatilitas arus kas suatu perusahaan maka semakin tinggi risiko yang dimilikinya (Hardiyanto, 2014).

Tabel 3. Rekapitulasi hasil estimasi parameter struktur modal

\begin{tabular}{|c|c|c|c|c|c|c|c|c|}
\hline \multirow{2}{*}{ Variabel } & \multicolumn{2}{|c|}{ TLKM } & \multicolumn{2}{|c|}{ ISAT } & \multicolumn{2}{|c|}{ EXCL } & \multicolumn{2}{|c|}{ FREN } \\
\hline & Coef & Prob & Coef & Prob & Coef & Prob & Coef & Prob \\
\hline $\mathrm{C}$ & $-0,885$ & 0,050 & $-38,534$ & 0,001 & $-7,341$ & 0,003 & $-0,181$ & 0,944 \\
\hline PROF & $-0,194$ & $0,005^{*}$ & 1,319 & $0,011 *$ & $-0,640$ & 0,259 & 0,012 & 0,942 \\
\hline AGE & 0,296 & $0,002 *$ & 1,546 & $0,002 *$ & $-1,176$ & $0,000 * *$ & 0,129 & 0,765 \\
\hline RISK & 0,021 & $0,020 *$ & 0,053 & 0,244 & $-0,036$ & $0,001^{*}$ & 0,052 & 0,427 \\
\hline SIZE & $-0,418$ & 0,145 & 2,819 & $0,001^{*}$ & 1,231 & $0,000 * *$ & $-0,005$ & 0,989 \\
\hline GROWTH & 0,052 & $0,002 *$ & 0,034 & 0,471 & $-0,044$ & 0,117 & $-0,888$ & 0,412 \\
\hline $\operatorname{DER}(-1)$ & $-0,842$ & $0,000 * *$ & 0,647 & $0,000 * *$ & 0,217 & 0,000 & 0,164 & 0,051 \\
\hline R-Squared & 0,841 & & 0,947 & & 0,968 & & 0,253 & \\
\hline F-statistic & 17,694 & & 59,635 & & 99,472 & & 1,129 & \\
\hline Prob (F-statistic) & 0,000 & & 0,000 & & 0,000 & & 0,381 & \\
\hline
\end{tabular}


Hasil regresi pada Tabel 3 menunjukkan TLKM dan EXCL memiliki nilai probability $\leq 0,05$, yaitu 0,020 dan 0.001 sementara ISAT dan FREN memiliki nilai probability $\geq 0,05$ yaitu 0,244 dan 0,427 . Hal ini menunjukkan bahwa bagi TLKM dan EXCL risiko perusahaan memiliki pengaruh terhadap DER, tetapi sebaliknya pada ISAT dan FREN risk tidak berpengaruh terhadap DER. Nilai koefisien sebesar 0,021 pada TLKM mengindikasikan bahwa risk memiliki pengaruh positif dengan demikian gagal menolak H0. Hasil penelitian ini sejalan penelitian yang dilakukan oleh Rahmatillah (2016), Ezeoha (2011), Su (2010) dan Jordan et al. (1998). Rahmatillah (2016) menemukan bahwa risiko mempunyai hubungan yang positif terhadap struktur modal. Jordan et al. (1998) mengatakan bahwa terdapat hubungan yang positif antara risiko perusahaan dengan struktur modal ketika perusahaan memiliki growth yang tinggi.

Nilai koefisien pada EXCL sebesar -0.036 mengindikasikan bahwa risiko memiliki pengaruh negatif signifikan terhadap DER yaitu setiap kenaikan risiko akan menurunkan DER. Dengan demikian H0 ditolak. Hal ini menandakan bahwa perusahaan dengan risiko bisnis yang semakin besar akan mengurangi utangnya karena terdapat kemungkinan mengalami financial distress. Abor (2009) juga menjelaskan hubungan negatif mengindikasikan bahwa perusahaan menerapkan prinsip trade off. Trade off theory menjelaskan bahwa perusahaan dengan risiko yang tinggi akan cenderung mengurangi utang. Hasil yang tidak signifikan pada ISAT dan FREN sejalan dengan penelitian Ezeoha (2011) dan $\mathrm{Su}$ (2010) dalam Rahmatillah (2016) menemukan bahwa risiko perusahaan berpengaruh tidak signifikan terhadap struktur modal.

Size

Size adalah ukuran perusahaan yang dalam penelitian ini dinyatakan dengan log natural dari total aset. Dalam perspektif teori trade off dan agency theory, size memiliki hubungan yang positif terhadap struktur modal. Teori ini mengasumsikan bahwa perusahaan yang besar memiliki kapasitas untuk meminjam lebih banyak utang.

Hasil regresi pada Tabel 3 menunjukkan ISAT dan EXCL memiliki nilai probability $\leq 0,05$, yaitu 0,001 dan 0,000 sementara TLKM dan FREN memiliki nilai probability $\geq 0,05$, yaitu 0,145 dan 0,412 . Hal ini menunjukkan bahwa bagi ISAT dan EXCL size perusahaan memiliki pengaruh terhadap DER sebaliknya pada TLKM dan FREN size tidak berpengaruh terhadap DER. Nilai koefisien sebesar 2,819 pada ISAT dan 1,231 pada EXCL mengindikasikan bahwa size memiliki pengaruh positif terhadap struktur modal dengan demikian $\mathrm{H} 0$ ditolak.

Hal ini sejalan dengan penelitian yang dilakukan oleh Flannery dan Rangan (2016) dan Avarmaa et al. (2011) yang menjelaskan bahwa perusahaan dengan jumlah aset yang besar memiliki debt ratio yang besar. Hal ini karena perusahaan dengan aset yang besar memiliki akses yang lebih mudah untuk mendapatkan utang. Perusahaan dengan size yang lebih besar dianggap memiliki risiko yang lebih rendah. Hal ini sejalan dengan trade off theory dan agency cost.

Berbeda dengan ISAT dan EXCL, size memiliki hubungan negatif tidak signifikan pada TLKM dan FREN. Hubungan negatif antara size dengan struktur modal sejalan dengan prinsip pecking order theory yang menjelaskan bahwa semakin besar ukuran perusahaan akan mengurangi utangnya. Perusahaan dengan ukuran yang besar memiliki kemampuan untuk membiayai perusahaan dengan pendanaan internal. Hasil penelitian ini juga sejalan dengan penelitian yang dilakukan oleh Rahmatillah (2016) yang melakukan penelitian pada perusahaan telekomunikasi di Indonesia tahun 20082015.

\section{Growth}

Growth dalam penelitian ini adalah pertumbuhan perusahaan yang dihitung dengan menggunakan proksi penjualan. Pertumbuhan perusahaan menjadi salah satu faktor pertimbangan dalam menetukan struktur modal. Perusahaan dengan tingkat pertumbuhan yang tinggi lebih banyak mengandalkan modal eksternal, agar dapat meningkatkan kapasitas produksi yang akan berdampak pada kenaikan penjualannya.

Hasil regresi pada Tabel 3 menunjukkan TLKM memiliki nilai probability $\leq 0,05$ yaitu 0,002 sementara ISAT, EXCL dan FREN memiliki nilai probability $\geq$ 0,05 yaitu $0,471,0,117$ dan 0,412 . Hal ini menunjukkan bahwa bagi TLKM variabel growth memiliki pengaruh terhadap struktur modal sementara bagi ISAT, EXCL dan FREN growth memiliki pengaruh tidak signifikan. 
Abor (2009) dan Hall et al. (2004) yang menunjukkan bahwa growth memiliki hubungan yang positif signifikan terhadap struktur modal. Viviani dalam Alipour et al. (2015) menjelaskan bahwa perusahaan dengan pertumbuhan yang tinggi akan cenderung menggunakan lebih banyak utang.

\section{Implikasi Manajerial}

Manajemen perusahaan perlu memperhatikan variabel karakteristik perusahaan tersebut. Karakteristik perusahaan menjadi salah satu faktor yang penting dalam mempengaruhi struktur modal. Karakteristik yang mempengaruhi struktur modal berbeda antar perusahaan. Oleh karena itu, pengelola perusahaan perlu memahami keadaan perusahaannya. Analisis struktur modal ini juga dapat dijadikan pengingat bagi manajemen apabila sudah melewati batas optimal penggunaan utang yang digambarkan dengan DER yang tinggi. Hal ini dikarenakan DER yang terlalu tinggi akan membawa perusahaan pada risiko financial distress. Kecepatan penyesuaian terhadap target struktur modal dapat memberikan informasi kepada manajemen sejauh mana perusahaan dapat menambah utangnya. Perusahaan lokal masih dapat menambah tingkat utangnya karena masih mampu membayar beban bunga. Sementara perusahaan asing sebaiknya tidak menambah utang karena saat ini sudah memiliki debt ratio yang tinggi sehingga apabila melakukan penambahan utang, maka akan menambah risiko perusahaan.

Bagi perbankan dan lembaga keuangan lainnya, analisis struktur modal perusahaan akan memberi gambaran terkait kebijakan pemberian kredit. Struktur modal memberikan gambaran pada perbankan terkait risiko keuangan perusahaan. Perbankan akan cenderung memberikan bunga yang tinggi pada perusahaan dengan risiko yang tinggi. Bunga yang tinggi ini sebagai trade off dari kemungkinan gagal bayar oleh perusahaan. Sementara perusahaan dengan struktur modal yang rendah cenderung memiliki risiko yang rendah. Dengan demikian, perbankan dapat menentukan kebijakannya dalam memberikan kredit. Pihak perbankan juga dapat mempertimbangkan variabel-variabel internal perusahaan yang digunakan dalam penelitian dalam mengevaluasi pemberian kredit. Hal ini dikarenakan variabel tersebut (profitability, age, risk, size, growth) terbukti secara statistik mempengaruhi struktur modal perusahaan. Bagi investor, analisis struktur modal akan membatu investor dalam membandingkan kinerja perusahaan sehingga investor dapat mengetahui perusahaan mana yang memiliki prospek paling baik. Hal ini dikarenakan analisis sruktur modal memberikan informasi risiko dan pengembalian perusahaan.

\section{KESIMPULAN DAN SARAN}

\section{Kesimpulan}

Hasil analisis struktur modal perusahaan telekomunikasi di Indonesia yang terdaftar pada Bursa Efek Indonesia periode tahun 2011 sampai 2017 menunjukkan bahwa perusahaan telekomunikasi di Indonesia selama periode tahun 2011 sampai 2017 lebih banyak menggunakan debt dibanding equity kecuali pada perusahaan TLKM. Sementara hasil uji variabel terhadap struktur modal perusahaan menunjukkan hasil dan pengaruh yang berbeda-beda. Profitability berpengaruh negatif signifikan terhadap struktur modal TLKM dan ISAT dan tidak berpengaruh pada EXCL dan FREN. Age berpengaruh positif signifikan pada TLKM dan ISAT dan berpengaruh negatif pada EXCL. Risk berpengaruh negatif signifikan pada EXCL dan berpengaruh positif pada TLKM dan ISAT. Size berpengaruh positif pada TLKM, ISAT dan EXCL. Growth berpengaruh positif pada TLKM, ISAT dan EXCL. Hal ini menunjukkan terdapat kebijakan struktur modal yang berbeda antar masing-masing perusahaan telekomunikasi di Indonesia selama periode tahun penelitian. Perubahan rasio masing-masing variabel menimbulkan perubahan pada struktur modal yang berbeda pula.

\section{Saran}

Penelitian ini menggunakan debt to equity ratio sebagai proksi dalam mengukur struktur modal, penelitian selanjutnya dapat menggunakan debt to total asset atau variabel lain sebagai proksi struktur modal. Mengingat pada salah satu perusahaan telekomunikasi terdapat ekuitas yang negatif sehingga harus dikeluarkan dari objek penelitian. Apabila penelitian selanjutnya menggunakan proksi lain selain ekuitas, terdapat kemungkinan seluruh perusahaan telekomunikasi yang terdaftar di Bursa Efek Indonesia dapat dijadikan objek penelitian. 
Penelitian selanjutnya juga dapat menggunakan periode waktu yang lebih panjang agar mendapat gambaran industri secara lebih menyeluruh. Analisis juga bisa dikaitkan dengan rencana penggabungan perusahaan telekomunikasi di Indonesia. Selain itu, penelitian selanjutnya juga dapat menggunakan variabel lain diluar penelitian ini dan menambahkan faktor eksternal atau faktor ekonomi makro dan menganalisis berdasarkan jenis kepemilikan seperti BUMN-Non BUMN.

\section{DAFTAR PUSTAKA}

Abor J, Biekpe 2005. The effect of capital structure on profitability: an empirical analysis of listed firms in Ghana. The Journal of Risk Finance 6(5):438-446. https://doi. org/10.1108/15265940510633505.

Abor J, Biekpe. 2009. How do we explain the capital structure of SMEs in Sub Sharan Africa? Evidence fron Ghana. Journal of Studies 36(1): 83-97. https://doi.org/10.1108/01443580910923812.

Acaravci K. 2015. The determinants of capital structure: evidence from the Turkish manufacturing sector. International Journal of Econmics and Financail Issues 5(1):158-171.

Ahmed R. 2012. Is there an optimal capital strucutr in the UK telecommunication industry. International Journal and Research in Finance and Marketing 2(2): 26-47.

Alipour M, Mohammadi MFS, Derakhshan. 2015. Determinants of capital structure: an empirical study of firms in Iran. International Journal of Law and Management 57(1): 53-58. https://doi. org/10.1108/IJLMA-01-2013-0004.

Astireou D, Hall SG. 2007. Applied Econometric A Modern Approach. Revised Edition. New York: Palgrave Macmillan

Bayrakdaroglu A, Ege I, Yazici N. 2013. A panel data analysis of capital structure determinants; empirical result from Turkish capital market. International Journal of Economics and Finance 5(4): 131-140. https://doi.org/10.5539/ijef. v5n 4 p 131 .

Brigham EF, Houston JF. 2006. Fundamnetals of Financial Management. Florida: Cengage Learning.

Effendi N, Setiawan M. 2014. Ekonometrika: Pendekatan Teori dan Terapan. Jakarta: Salemba Empat

Ezeoha AE, Okafor FO. 2010. Local corporate ownership and capital structure decisions in Nigerian a developing country perspective corporate governance. The International Journal of Business in Society 10(3): 249-260. https:// doi.org/10.1108/14720701011051893.

Fama EF, French KR. 2015. Testing trade off and pecking order predictions about dividends and debt. The Review of Financial Studies 15(1):133. https://doi.org/10.1093/rfs/15.1.1.

Firdaus M. 2011. Aplikasi Ekonometrika Untuk Data Panel dan Time Series. Bogor: IPB Press.

Flannery MJ, Rangan KP. 2006. Partial adjustment toward target capital structure. Journal of Financial Economics 67(1):217-248.

Gitman LJ. 2006. Principles of Managerial Finance, Seventeenth Edition. Massachusetts: AddisonWesley Publishing Company

Hall et al. 2004. Determinants of capital structure of European SMEs. Journal of Business Finance and Accounting 31(5/6): 711-28. https://doi. org/10.1111/j.0306-686X.2004.00554.x.

Hardiyanto AT. 2014. Analisis Determinan Dan Teori Trade Off Struktur Modal Perusahaan Masuk Bursa Di Indonesia [disertasi]. Bogor: Institut Pertanian Bogor.

Hendrawan R, Nugraha DA. 2015. The test of speed of adjustment towards the capital structure in Indonesia telecommunication industry. Jurnal Keuangan dan Perbankan 19: 263-170

Heshmati A. 2001. On the growth of micro and small firms: evidence from Sweden. Small Business Economics 17: 213-228. https://doi.org/10.1023/ A:1011886128912..

Jordan J et al. 1998. Strategy and financial policy in UK small firms. Journal of Business Finance and Accounting 25(1\&2):1-27. https://doi. org/10.1111/1468-5957.00176.

Komara A. 2014. Analisis Struktur Modal Dan Pengaruhnya Terhadap Kinerja Keuangan Perusahaan (Studi Kasus Pada Perusahaan Pembiayaan yang terdaftar di BEI periode 20092013 [tesis]. Bogor: Institut Pertanian Bogor.

Kpouki M, Said HB. 2012. Capital structure determinants: new evidence from French panel data. International Jpurnal of Business and Management 7(1):214-229.

Lasher, William R. 2003. Practical Financial Management. 3 th edition. Southwestern: Thompson Learning

Maghyereh A. 2005. Dynamic capital structure: evidence from the small developing country 
of Jprdan. IIUM Journal of Economis and Managementi 13(2):1-32.

Maharani DA, Wulandari HW. Penggabungan, peleburan dan pengambilalihan pada industri telekomunikasi di Indonesia. Jurnal Penelitian Pos dan Informatika 1(15): 19-36. https://doi. org/10.17933/jppi.2015.0501002.

Majumdar SK, Chhibber PK. 2014. Capital structure and performance: evidnce from a transition economy on as aspect of corporate governance. Public Choice 98(3-4):287-305. https://doi. org/10.1023/A:1018355127454.

Muzir E. 2011. Triangle relationship among firm size, capital structure choice and financial performance. Journal of Management Research 11(2):87-89.

Rahmatillah I, Prasetyo DA. 2016. Determinants of capital structure analysis: empirical study of telecommunication industry in Indonesia 20082015. Journal of Business and Management 5(3): 414-435.

Sitorus PM. 2014. Analisis Struktur Modal Pada Perusahaan Telekomunikasi di Indonesia [disertasi]. Bogor: Institut Pertanian Bogor.

Sivathaasan N. 2013. Foreign ownership, domestic ownership and capital structure:special reference to manufacturing companies quoted on Colombo stock exchange in Sri Lanka. European Journal of Business and Management 5(20): 35-41.

$\mathrm{Su}$ DL. 2010. Ownership structure, corporate diversification and capital structure, management decision. Emerald Journal 12(48): 314-339. https://doi.org/10.1108/00251741011022644.

Untung S, Siregar H, Anggraeni L. 2017. Struktur modal dan modal kerja pada PT XYZ serta pengaruhnya terhadap kinerja perusahaan. Jurnal Aplikasi Bisnis dan Manajemen 3(1):131-142. https:// doi.org/10.17358/jabm.3.1.131

Utomo P, Djumahir. 2013. Pengaruh variabel fundamental terhadap struktur modal dan dampaknya terhadap nilai perusahaan. Jurnal Aplikasi Manajemen 2(3):374-383.

Yartey, Abor. 2013. Financial market development and capital structure flisted firms: empirical evidence from Ghana. Serbian Journal of Management 6(2): 155-168. https://doi.org/10.5937/ sjm1102155D.

Yoshendy A. 2014. Analisis struktur modal pada perusahaan barang konsumsi di bursa efek Indonesia Tahun 2002-2011 [tesis]. Bogor: Institut Pertanian Bogor. 